\title{
Nocardioides aquiterrae sp. nov., isolated from groundwater in Korea
}

Correspondence
Yong-Ha Park
yhpark@kribb.re.kr

The first described Nocardioides species were mainly isolated from various soils. Nocardioides albus and Nocardioidesluteus were respectively isolated from soils collected in different parts of the world and soil of subtropical regions (Prauser, 1976, 1989). The type strain of Nocardioides simplex was isolated from rice soil (Jensen, 1934) and atypical N. simplex strains were isolated from soil of the petroleum zone in Japan (Iizuka \& Komagata, 1964). Subsequently, Nocardioides species have been found in habitats other than soils, such as herbage (Nocardioides plantarum; Collins et al., 1994), an oil shale column (Nocardioides pyridinolyticus; Yoon et al., 1997) and industrial wastewater (Nocardioides nitrophenolicus; Yoon et al., 1999). Recently, Nocardioides aquaticus was isolated from an aquatic rather than a terrestrial environment. It was isolated from water of the

Published online ahead of print on 8 August 2003 as DOI 10.1099/ ijs.0.02585-0.

Abbreviation: DAP, 2,6-diaminopimelic acid.

The GenBank accession number for the $16 \mathrm{~S}$ rDNA sequence of strain $\mathrm{GW}-9^{\top}$ is AF529063. hypersaline and meromictic Ekho Lake, located in the icefree area of the Vestfold Hills in East Antarctica (Lawson et al., 2000). These facts indicate that Nocardioides species are widely distributed in nature.

In this study, an LL-2,6-diaminopimelic acid (DAP)containing actinomycete, GW- $9^{\mathrm{T}}$, isolated from groundwater in Korea, is described. This isolate was considered to be a Nocardioides-like strain from $16 \mathrm{~S}$ rDNA sequence comparisons, as well as the presence of LL-DAP. Accordingly, the aim of the present study was to determine the exact taxonomic status of strain $\mathrm{GW}-9^{\mathrm{T}}$ using a combination of phenotypic properties, detailed phylogenetic analysis based on $16 \mathrm{~S}$ rDNA sequence and genomic relatedness. On the basis of the data presented below, it is proposed that strain $\mathrm{GW}-9^{\mathrm{T}}$ represents a novel species in the genus Nocardioides, for which the name Nocardioides aquiterrae sp. nov. is proposed.

Strain $\mathrm{GW}-9^{\mathrm{T}}$ was isolated by the usual dilution plating technique on nutrient agar (NA; Difco) at $30^{\circ} \mathrm{C}$. Type strains of Nocardioides species used as reference organisms for DNA-DNA hybridization were obtained from the 
DSMZ (Deutsche Sammlung von Mikroorganismen und Zellkulturen) and KCTC (Korean Collection for Type Cultures). Strain $\mathrm{GW}-9^{\mathrm{T}}$ was cultivated on NA and in nutrient broth (NB; Difco) at $30^{\circ} \mathrm{C}$ to investigate its morphological and physiological characteristics. Cell mass of strain $\mathrm{GW}-9^{\mathrm{T}}$ for analyses of the cell wall and menaquinones was obtained from NB culture at $30^{\circ} \mathrm{C}$. Cell mass of strain GW $-9^{\mathrm{T}}$ and reference strains for DNA extraction was produced in NB. For fatty acid methyl ester analysis, cell mass of strain $\mathrm{GW}-9^{\mathrm{T}}$ was obtained from agar plates after 6 days cultivation at $30^{\circ} \mathrm{C}$ on NA. Cell morphology was examined by light microscopy (Nikon E600) and TEM. The presence or absence of flagella was determined using TEM with cells from exponentially growing cultures. For TEM observation, cells were negatively stained with $1 \%(\mathrm{w} / \mathrm{v})$ phosphotungstic acid and, after air drying, the grids were examined with a model CM-20 TEM (Philips). Oxidase activity was determined by oxidation of $1 \%(\mathrm{w} / \mathrm{v}) p$ aminodimethylaniline oxalate. Catalase activity was determined by bubble production in a $3 \%(\mathrm{v} / \mathrm{v})$ hydrogen peroxide solution. Hydrolysis of aesculin and nitrate reduction were determined as described previously (Lanyi, 1987). Hydrolysis of casein, gelatin, hypoxanthine, starch, Tween 80 , tyrosine and xanthine and urease activity were determined as described by Cowan \& Steel (1965). Utilization of various substrates as sole carbon and energy sources was determined as described by Shirling \& Gottlieb (1966). Growth under anaerobic conditions was determined after incubation in an anaerobic chamber with NA that had been prepared anaerobically. Growth at various temperatures $\left(4-55^{\circ} \mathrm{C}\right)$ was determined on NA.

The isomer type of the diamino acid in the cell-wall peptidoglycan was analysed using TLC according to the method described by Komagata \& Suzuki (1987). Menaquinones were analysed as described previously (Komagata \& Suzuki, 1987) using reversed-phase HPLC. For quantitative analysis of the cellular fatty acid content, a loopful of cell mass was harvested and fatty acid methyl esters were prepared and identified according to the instructions of the Microbial Identification System (MIDI). Chromosomal DNA was isolated and purified according to Yoon et al. (1996), with the exception that ribonuclease T1 was used together with ribonuclease $\mathrm{A}$. The $\mathrm{G}+\mathrm{C}$ content was determined by the method of Tamaoka \& Komagata (1984). DNA was hydrolysed and the resultant nucleotides were analysed by reversed-phase HPLC.

$16 \mathrm{~S}$ rDNA was amplified by PCR using two universal primers as described previously (Yoon et al., 1998). The PCR product was purified with a QIAquick PCR purification kit (Qiagen). Sequencing of the purified $16 \mathrm{~S}$ rDNA was performed using an ABI PRISM BigDye Terminator cycle sequencing ready reaction kit (Applied Biosystems) as recommended by the manufacturer. Purified sequencing reaction mixtures were electrophoresed automatically using an Applied Biosystems model 377 automatic DNA sequencer. Alignment of sequences was carried out with CLUSTAL W software (Thompson et al., 1994). Gaps at the 5' and 3' ends of the alignment were omitted from further analysis. Phylogenetic trees were inferred using three tree-making algorithms, the neighbour-joining (Saitou \& Nei, 1987), maximum-likelihood (Felsenstein, 1981) and maximumparsimony (Kluge \& Farris, 1969) methods in the PHYLIP package (Felsenstein, 1993). Evolutionary distance matrices for the neighbour-joining method were calculated using the algorithm of Jukes \& Cantor (1969) with the program DNADIST. The stability of relationships was assessed by bootstrap analysis based on 1000 resamplings of the neighbourjoining dataset using the programs SEQBOOT, DNADIST, NEIGHBOR and CONSENSE of the PHYLIP package. DNA-DNA hybridization was performed fluorometrically by the method of Ezaki et al. (1989) using photobiotin-labelled DNA probes and microdilution wells. Hybridization was performed with five replications for each sample. Of the values obtained, the highest and lowest values in each sample were excluded and the means of the remaining three values were taken as DNA relatedness values.

Physiological and biochemical characteristics of strain $\mathrm{GW}-9^{\mathrm{T}}$ are given in the species description below and are compared with those of $N$. pyridinolyticus in Table 1 .

Strain GW $-9^{\mathrm{T}}$ contained LL-DAP as the diagnostic diamino acid in the cell wall, which is characteristic of wall chemotype I sensu Lechevalier \& Lechevalier (1970). The predominant isoprenoid quinone found in strain $\mathrm{GW}-9^{\mathrm{T}}$ was tetrahydrogenated menaquinone with eight isoprene units $\left[\mathrm{MK}-8\left(\mathrm{H}_{4}\right)\right]$. Strain GW-9 $9^{\mathrm{T}}$ had a cellular fatty acid profile containing large amounts of straight-chain, branched, unsaturated and 10-methyl fatty acids. The major fatty acid

Table 1. Differential phenotypic characteristics of strain $\mathrm{GW}-9^{\top}$ and N. pyridinolyticus

Data for N. pyridinolyticus were taken from Yoon et al. (1997). + , Positive; -, negative; $\mathrm{w}+$, weakly positive. Both species are rods or cocci, positive for motility, catalase, nitrate reduction, hydrolysis of aesculin and gelatin and utilization of D-cellobiose, D-fructose, Dgalactose, D-glucose, lactose, maltose, D-mannose, sucrose, D-trehalose, D-xylose and D-mannitol. Both species are negative for utilization of Larabinose, D-melibiose, D-raffinose, stachyose, adonitol and D-sorbitol.

\begin{tabular}{|lcc|}
\hline Characteristic & Strain GW-9 & N. pyridinolyticus $^{\mathbf{T}}$ \\
\hline Flagellation & Single lateral & Single polar \\
Utilization of: & - & \\
myo-Inositol & $\mathrm{W}+$ & + \\
D-Ribose & - & + \\
D-Melezitose & $\mathrm{W}+$ & + \\
L-Rhamnose & 30 & + \\
Optimum growth & & 35 \\
temperature $\left({ }^{\circ} \mathrm{C}\right)$ & $6 \cdot 0-7 \cdot 0$ & $8 \cdot 0$ \\
Optimum growth $\mathrm{pH}$ & Groundwater & Oil shale column \\
Isolation source & & \\
\hline
\end{tabular}


Table 2. Cellular fatty acid content of strain $\mathrm{GW}-9^{\top}, N$. pyridinolyticus $\mathrm{KCTC} 0074 \mathrm{BP}^{\top}$ and $N$. albus $\mathrm{KCTC} 9186^{\top}$

Strains: 1 , GW $-9^{\mathrm{T}} ; 2$, N. pyridinolyticus KCTC $0074 \mathrm{BP}^{\mathrm{T}} ; 3$, N. albus KCTC $9186^{\mathrm{T}}$. Data for reference strains were taken from Yoon et al. (1997). Values are percentages of total fatty acids. Fatty acids representing less than $0 \cdot 5 \%$ were omitted. ND, Not detected; TBSA, tuberculostearic acid.

\begin{tabular}{|c|c|c|c|}
\hline Fatty acid & 1 & 2 & 3 \\
\hline \multicolumn{4}{|c|}{ Straight-chain fatty acids } \\
\hline $\mathrm{C}_{15: 0}$ & $0 \cdot 4$ & $0 \cdot 4$ & $0 \cdot 7$ \\
\hline $\mathrm{C}_{16: 0}$ & $0 \cdot 5$ & $1 \cdot 2$ & $0 \cdot 7$ \\
\hline $\mathrm{C}_{17: 0}$ & $0 \cdot 5$ & $1 \cdot 2$ & $1 \cdot 5$ \\
\hline $\mathrm{C}_{18: 0}$ & $0 \cdot 3$ & $1 \cdot 0$ & ND \\
\hline \multicolumn{4}{|l|}{ Branched fatty acids } \\
\hline iso- $\mathrm{C}_{14: 0}$ & $1 \cdot 5$ & $0 \cdot 5$ & $2 \cdot 2$ \\
\hline iso- $\mathrm{C}_{15: 0}$ & $4 \cdot 9$ & $5 \cdot 1$ & $3 \cdot 1$ \\
\hline anteiso- $\mathrm{C}_{15: 0}$ & $2 \cdot 4$ & $1 \cdot 4$ & $\mathrm{ND}$ \\
\hline iso- $\mathrm{C}_{16: 0}$ & $57 \cdot 6$ & $47 \cdot 3$ & $53 \cdot 6$ \\
\hline iso- $\mathrm{C}_{16: 1} \mathrm{H}^{*}$ & $6 \cdot 8$ & $4 \cdot 2$ & $1 \cdot 1$ \\
\hline iso- $\mathrm{C}_{17: 0}$ & $0 \cdot 7$ & $1 \cdot 7$ & $1 \cdot 3$ \\
\hline anteiso- $\mathrm{C}_{17: 0}$ & $9 \cdot 0$ & $14 \cdot 2$ & $0 \cdot 7$ \\
\hline anteiso- $\mathrm{C}_{17: 1} \omega 9 c$ & $2 \cdot 4$ & $2 \cdot 1$ & ND \\
\hline iso- $\mathrm{C}_{18: 0}$ & $0 \cdot 2$ & $0 \cdot 5$ & $0 \cdot 9$ \\
\hline \multicolumn{4}{|c|}{ Unsaturated fatty acids } \\
\hline $\mathrm{C}_{17: 1} \omega 6 c$ & ND & ND & $15 \cdot 6$ \\
\hline $\mathrm{C}_{17: 1} \omega 8 c$ & $1 \cdot 7$ & $1 \cdot 7$ & $2 \cdot 8$ \\
\hline $\mathrm{C}_{18: 1} \omega 9 c$ & $0 \cdot 9$ & $2 \cdot 0$ & ND \\
\hline \multicolumn{4}{|l|}{ 10-Methyl fatty acids } \\
\hline $10-\mathrm{Me} \mathrm{C}_{16: 0}$ & $3 \cdot 4$ & $5 \cdot 0$ & $1 \cdot 5$ \\
\hline $10-\mathrm{Me} \mathrm{C}_{17: 0}$ & $4 \cdot 1$ & $5 \cdot 5$ & $12 \cdot 2$ \\
\hline $10-\mathrm{Me} \mathrm{C}_{18: 0}$ (TBSA) & $0 \cdot 8$ & $3 \cdot 4$ & $2 \cdot 3$ \\
\hline Summed feature $3 \dagger$ & $0 \cdot 7$ & $0 \cdot 8$ & ND \\
\hline
\end{tabular}

${ }^{*}$ Double bond position indicated by a capital letter is unknown. $\dagger$ Contains one or both of iso- $\mathrm{C}_{15: 0} 2-\mathrm{OH}$ and/or $\mathrm{C}_{16: 1} \omega 7 c$, which could not be separated by GLC with the MIDI system. was iso- $\mathrm{C}_{16: 0}$. This cellular fatty acid profile is similar to those of Nocardioides species (Yoon et al., 1997, 1999), particularly the type strain of $N$. pyridinolyticus (Table 2), although there are differences in the proportions of some fatty acids. The DNA G $+C$ content of strain $\mathrm{GW}-9^{\mathrm{T}}$ was $73 \mathrm{~mol} \%$.

The almost complete $16 \mathrm{~S}$ rDNA sequence of strain GW $-9^{\mathrm{T}}$ was determined directly following PCR amplification. The sequence comprised $1484 \mathrm{nt}$, representing approximately $96 \%$ of the Escherichia coli 16S rRNA sequence. Phylogenetic trees based on $16 \mathrm{~S}$ rDNA sequences showed that strain $\mathrm{GW}-9^{\mathrm{T}}$ falls within the radiation of the cluster comprising Nocardioides species. In the tree based on the neighbour-joining algorithm, strain $\mathrm{GW}-9^{\mathrm{T}}$ formed a coherent cluster with $N$. pyridinolyticus by bootstrap analysis at a confidence level of $100 \%$ (Fig. 1). The same tree topology was also found in phylogenetic trees generated with maximumparsimony and maximum-likelihood algorithms (data not shown). The level of $16 \mathrm{~S}$ rDNA similarity between strain GW $-9^{\mathrm{T}}$ and the type strain of N. pyridinolyticus was $99 \cdot 2 \%$. Strain $\mathrm{GW}-9^{\mathrm{T}}$ exhibited $16 \mathrm{~S}$ rDNA similarities of $94 \cdot 9-$ $96.0 \%$ with the type strains of other Nocardioides species with validly published names and 89.9-94.2\% with members of other genera used in the phylogenetic analysis. Two independent levels of DNA-DNA relatedness between GW $-9^{\mathrm{T}}$ and $N$. pyridinolyticus KCTC $0074 \mathrm{BP}^{\mathrm{T}}$, its phylogenetic neighbour, were 32.5 and $28 \cdot 7 \%$, when each of their DNAs was used separately as the labelled DNA probe. Strains GW $-9^{\mathrm{T}}$ exhibited levels of DNA-DNA relatedness of $8 \cdot 7-15 \cdot 3 \%$ with the type strains of other Nocardioides species with validly published names.

16S rDNA sequence data showed that strain GW $-9^{\mathrm{T}}$ exhibited the closest phylogenetic affinity to Nocardioides species. Phylogenetic analysis based on $16 \mathrm{~S}$ rDNA sequences placed strain GW $-9^{\mathrm{T}}$ within a phyletic cluster comprising Nocardioides species (Fig. 1). Results obtained in the chemotaxonomic analysis are consistent with the results of phylogenetic inference based on 16S rDNA sequences. The chemotaxonomic

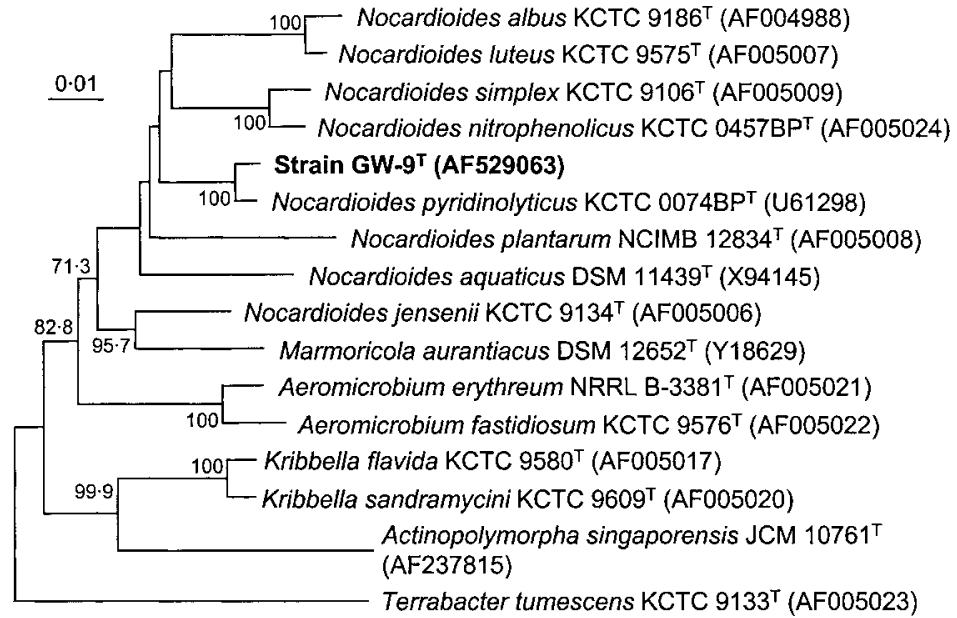

Fig. 1. Neighbour-joining tree showing the phylogenetic positions of strain $\mathrm{GW}-9^{\top}$, Nocardioides species and some other related taxa based on $16 \mathrm{~S}$ rDNA sequences. Bar, 0.01 substitutions per nucleotide position. Bootstrap values (expressed as percentages of 1000 replications) greater than $50 \%$ are shown at branch points. 
data obtained from strain $\mathrm{GW}-9^{\mathrm{T}}$ are most similar to those of members of the genus Nocardioides in the family Nocardioidaceae (Miller et al., 1991; Park et al., 1999; Urzì et al., 2000; Wang et al., 2001). Of genera belonging to the family Nocardioidaceae, two genera, Nocardioides and Marmoricola, have been known to contain MK-8 $\left(\mathrm{H}_{4}\right)$ as the predominant menaquinone. However, the genus Marmoricola contains $\mathrm{C}_{16: 0}$ and $\mathrm{C}_{18: 1}$ as the major fatty acids, which distinguishes it from the genus Nocardioides (Urzì et al., 2000). Therefore, both phylogenetic and chemotaxonomic results clearly indicate that strain $\mathrm{GW}-9^{\mathrm{T}}$ belongs to the genus Nocardioides. Strain GW- $9^{\mathrm{T}}$ was very similar to $N$. pyridinolyticus in its morphological and physiological properties, as shown in the phylogenetic analysis. The levels of DNA-DNA relatedness, together with minor differential phenotypic properties and phylogenetic distinctiveness, reveal that strain GW- $9^{\mathrm{T}}$ is distinct from previously described Nocardioides species, as well as $N$. pyridinolyticus, its closest phylogenetic neighbour (Wayne et al., 1987). Therefore, on the basis of the data presented, strain $\mathrm{GW}-9^{\mathrm{T}}$ should be placed in the genus Nocardioides as a representative of a novel species, for which the name Nocardioides aquiterrae sp. nov. is proposed.

\section{Description of Nocardioides aquiterrae sp. nov.}

Nocardioides aquiterrae (a.qui.ter'rae. L. n. aqua water; L. gen. fem. n. terrae of earth or ground; N.L. gen. fem. n. aquiterrae from/of groundwater).

Cells are aerobic, non-spore-forming, non-acid-fast rods, $0 \cdot 8-1 \cdot 0 \times 1 \cdot 7-2 \cdot 0 \mu \mathrm{m}$ in the exponential phase of growth after approximately 7 days incubation at $30{ }^{\circ} \mathrm{C}$ on NA. Motile by means of a single lateral flagellum. Cells show rodto-coccus morphogenesis from the early exponential phase to the stationary phase. Gram-positive (Gram-variable in old cultures). Colonies are smooth, circular, convex, creamcoloured and $0 \cdot 5-1 \cdot 0 \mathrm{~mm}$ in diameter after 7 days incubation on NA. Neither substrate nor primary mycelium is formed. Optimal temperature for growth is $30^{\circ} \mathrm{C}$; grows at 15 and $42{ }^{\circ} \mathrm{C}$, but not at $10^{\circ} \mathrm{C}$ or temperatures above $43^{\circ} \mathrm{C}$. Optimal pH for growth is $6 \cdot 0-7 \cdot 0$; no growth at $\mathrm{pH} 5 \cdot 0$. Oxidase-positive. Urease-negative. Casein and Tween 80 are hydrolysed. Hypoxanthine, starch, tyrosine and xanthine are not hydrolysed. The cell-wall peptidoglycan contains LL-DAP as the diagnostic diamino acid. The predominant menaquinone is MK- $8\left(\mathrm{H}_{4}\right)$. The cellular fatty acids consist of straight-chain, branched, unsaturated and 10-methyl fatty acids. The major fatty acid is iso- $\mathrm{C}_{16: 0}$. The DNA G+C content of the type strain is $73 \mathrm{~mol} \%$ (determined by HPLC). Other characteristics are given in Table 1.

The type strain, strain GW $-9^{\mathrm{T}}\left(=\mathrm{KCCM} 41647^{\mathrm{T}}=\mathrm{JCM}\right.$ $\left.11813^{\mathrm{T}}\right)$, was isolated from groundwater in Korea.

\section{Acknowledgements}

This work was supported by the NRL research programme (grants M10104000294-01J000012800 and M10104000294-01J000012811) and the $21 \mathrm{C}$ Frontier programme of Microbial Genomics and
Applications (grant MG02-0401-001-1-0-0) from the Ministry of Science and Technology (MOST) of the Republic of Korea and by the research fund of the Probionic Corporation of Korea.

\section{References}

Collins, M. D., Cockcroft, S. \& Wallbanks, S. (1994). Phylogenetic analysis of a new LL-diaminopimelic acid-containing coryneform bacterium from herbage, Nocardioides plantarum sp. nov. Int J Syst Bacteriol 44, 523-526.

Cowan, S. T. \& Steel, K. J. (1965). Manual for the Identification of Medical Bacteria. London: Cambridge University Press.

Ezaki, T., Hashimoto, Y. \& Yabuuchi, E. (1989). Fluorometric deoxyribonucleic acid-deoxyribonucleic acid hybridization in microdilution wells as an alternative to membrane filter hybridization in which radioisotopes are used to determine genetic relatedness among bacterial strains. Int J Syst Bacteriol 39, 224-229.

Felsenstein, J. (1981). Evolutionary trees from DNA sequences: a maximum likelihood approach. J Mol Evol 17, 368-376.

Felsenstein, J. (1993). PHYLIP (phylogenetic inference package), version 3.5. Distributed by the author. Department of Genetics, University of Washington, Seattle, USA.

lizuka, H. \& Komagata, K. (1964). Microbiological studies on petroleum and natural gas. I. Determination of hydrocarbonutilizing bacteria. J Gen Appl Microbiol 10, 207-221.

Jensen, H. L. (1934). Studies on saprophytic mycobacteria and corynebacteria. Proc Linn Soc N SW 59, 19-61.

Jukes, T. H. \& Cantor, C. R. (1969). Evolution of protein molecules. In Mammalian Protein Metabolism, vol. 3, pp. 21-132. Edited by H. N. Munro. New York: Academic Press.

Kluge, A. G. \& Farris, F. S. (1969). Quantitative phyletics and the evolution of anurans. Syst Zool 18, 1-32.

Komagata, K. \& Suzuki, K. (1987). Lipid and cell-wall analysis in bacterial systematics. Methods Microbiol 19, 161-206.

Lanyi, B. (1987). Classical and rapid identification methods for medically important bacteria. Methods Microbiol 19, 1-67.

Lawson, P. A., Collins, M. D., Schumann, P., Tindall, B. J., Hirsch, P. \& Labrenz, M. (2000). New LL-diaminopimelic acid-containing actinomycetes from hypersaline, heliothermal and meromictic Antarctic Ekho Lake: Nocardioides aquaticus sp. nov. and Friedmanniella lacustris sp. nov. Syst Appl Microbiol 23, 219-229.

Lechevalier, M. P. \& Lechevalier, H. A. (1970). A critical evaluation of the genera of aerobic actinomycetes. In The Actinomycetales, pp. 393-405. Edited by H. Prauser. Jena: Gustav Fischer.

Miller, E. S., Woese, C. R. \& Brenner, S. (1991). Description of the erythromycin-producing bacterium Arthrobacter sp. strain NRRL B-3381 as Aeromicrobium erythreum gen. nov., sp. nov. Int J Syst Bacteriol 41, 363-368.

Park, Y.-H., Yoon, J.-H., Shin, Y. K., Suzuki, K., Kudo, T., Seino, A., Kim, H.-J., Lee, J.-S. \& Lee, S. T. (1999). Classification of 'Nocardioides fulvus' IFO 14399 and Nocardioides sp. ATCC 39419 in Kribbella gen. nov., as Kribbella flavida sp. nov. and Kribbella sandramycini sp. nov. Int J Syst Bacteriol 49, 743-752.

Prauser, H. (1976). Nocardioides, a new genus of the order Actinomycetales. Int J Syst Bacteriol 26, 58-65.

Prauser, H. (1989). Genus Nocardioides Prauser 1976. In Bergey's Manual of Systematic Bacteriology, vol. 4, pp. 2371-2375. Edited by S. T. Williams, M. E. Sharpe \& J. G. Holt. Baltimore: Williams \& Wilkins.

Saitou, N. \& Nei, M. (1987). The neighbor-joining method: a new method for reconstructing phylogenetic trees. Mol Biol Evol 4, 406-425. 
Shirling, E. B. \& Gottlieb, D. (1966). Methods for characterization of Streptomyces species. Int J Syst Bacteriol 16, 313-340.

Tamaoka, J. \& Komagata, K. (1984). Determination of DNA base composition by reversed-phase high-performance liquid chromatography. FEMS Microbiol Lett 25, 125-128.

Thompson, J. D., Higgins, D. G. \& Gibson, T. J. (1994). CLUSTAL W: improving the sensitivity of progressive multiple sequence alignment through sequence weighting, position-specific gap penalties and weight matrix choice. Nucleic Acids Res 22, 4673-4680.

Urzi, C., Salamone, P., Schumann, P. \& Stackebrandt, E. (2000). Marmoricola aurantiacus gen. nov., sp. nov., a coccoid member of the family Nocardioidaceae isolated from a marble statue. Int J Syst Evol Microbiol 50, 529-536.

Wang, Y. M., Zhang, Z. S., Xu, X. L., Ruan, J. S. \& Wang, Y. (2001). Actinopolymorpha singaporensis gen. nov., sp. nov., a novel actinomycete from the tropical rainforest of Singapore. Int J Syst Evol Microbiol 51, 467-473.
Wayne, L. G., Brenner, D. J., Colwell, R. R. \& 9 other authors (1987). International Committee on Systematic Bacteriology. Report of the ad hoc committee on reconciliation of approaches to bacterial systematics. Int J Syst Bacteriol 37, 463-464.

Yoon, J.-H., Kim, H., Kim, S.-B., Kim, H.-J., Kim, W. Y., Lee, S. T., Goodfellow, M. \& Park, Y.-H. (1996). Identification of Saccharomonospora strains by the use of genomic DNA fragments and rRNA gene probes. Int J Syst Bacteriol 46, 502-505.

Yoon, J.-H., Rhee, S.-K., Lee, J.-S., Park, Y.-H. \& Lee, S. T. (1997). Nocardioides pyridinolyticus sp. nov., a pyridine-degrading bacterium isolated from the oxic zone of an oil shale column. Int J Syst Bacteriol 47, 933-938.

Yoon, J.-H., Lee, S. T. \& Park, Y.-H. (1998). Inter- and intraspecific phylogenetic analysis of the genus Nocardioides and related taxa based on 16S rDNA sequences. Int J Syst Bacteriol 48, 187-194.

Yoon, J.-H., Cho, Y.-G., Lee, S. T., Suzuki, K., Nakase, T. \& Park, Y.-H. (1999). Nocardioides nitrophenolicus sp. nov., a p-nitrophenoldegrading bacterium. Int J Syst Bacteriol 49, 675-680. 